ISA

Arboriculture \& Urban Forestry 2016. 42(2): 95-101

\title{
The Efficacy of Paclobutrazol Soil Application as it Relates to the Timing of Utility Right-of- Way Pruning
}

\author{
Chris Haugen, Kevin Tucker, Alex Smalling, Emily Bick, Steve Hoover, \\ Grant Ehlen, Todd Watson, and Shawn Bernick
}

\begin{abstract}
The plant growth regulator paclobutrazol's effect on live oak trees (Quercus virginiana) was evaluated to determine optimum timing of application and pruning time in Louisiana. Variables considered included length of branch regrowth, branch distance to conductor, pruning time and biomass chipping time. Data were evaluated to determine the ideal application timing of paclobutrazol relative to time of pruning. Live oak trees treated with paclobutrazol had significantly reduced branch regrowth, pruning time and chipping time, as compared to control trees regardless of application timing. Paclobutrazol application on live oak trees was idealized within 90 days pre- to 90 days post-prune. Economically, significant gains were found by utilizing this tool ranging from 180 days pre- to 180 days post-prune, allowing for application timing flexibility to reduce the growth of trees near power lines. Paclobutrazol treated live oak trees demonstrated significantly less re-growth response.

Key Words. Integrated Vegetation Management; Live Oak; Louisiana; Paclobutrazol; PBZ; Plant Growth Regulator; Quercus virginiana; Utility Vegetation Management.
\end{abstract}

Paclobutrazol (PBZ) is a plant growth regulator that suppresses the synthesis of gibberellin, a hormone that triggers cell elongation in shoots and leaves (Bai et al. 2004). Additionally, plant health benefits have been documented due to an increase in fibrous root development, an increase in the ability to maintain water, and a reduction of plant pathogenic fungi (Gillespie and Chaney 1989; Jacobs and Berg 2000; Bai et al. 2004). PBZ is currently being used to reduce stem elongation of trees and shrubs by multiple industries, including the electrical utility market.

Utility vegetation management is an integral component of maintaining safe and reliable distribution of electricity. An estimated USD \$20 to $\$ 55$ billion annually are lost by the U.S. economy due to storm-related outages in the power grid (Campbell 2012). To prevent these damages, the North American Electric Reliability Corporation put vegetation management standards in place to reduce incidents. Tree pruning in the utility corridor mitigates storm-related damage to power transmission and distribution. Lineclearance pruning results in resurgent growth that requires regularly scheduled observation and re-pruning. Plant growth regulators allow for slowed growth of vegetation near utility lines, increasing the time interval between prunings and reducing the likelihood of unsafe power outages (Burch and Wells 1995; Mann et al. 1995). PBZ reduced annual shoot growth in white and red oak (Quercus alba and Quercus rubra) up to $68 \%$, resulting in a $68 \%$ reduction of pruning and service visits (Bai et al. 2004).

The International Society of Arboriculture (ISA) recommends applying plant growth regulators two to three months before pruning for ideal results or at pruning time for acceptable results (ISA 2002). Although the effects of PBZ have been well documented, the relationship between soil application of PBZ, tree pruning, and resurgent growth has not been extensively researched. 
Previous work indicates that PBZ may significantly reduce the time required for utility lineclearance pruning operations due to its effect of reducing regrowth. The purpose of this trial was a) to investigate proper timing of PBZ soil applications and pruning events effect on resurgent growth in live oak trees (Quercus virginiana), b) to explore the amount of time crews spent on-site pruning and processing biomass from a pruning event after trees were treated with $\mathrm{PBZ}$, and c) to relate biomass reduction due to $\mathrm{PBZ}$ application to economic cost.

\section{MATERIALS AND METHODS}

Forty-eight live oak trees were randomly selected from one Entergy Louisiana, LLC. distribution circuit in a mixed residential and commercial neighborhood in Baton Rouge, Louisiana, U.S. All trees are located in urban environments adjacent to roadways or commercial structures. Trees were selected in proximity to energized distribution lines and were accessible to a utility line-clearance contractor with a hydraulic bucket for pruning. All trees were measured for initial diameter at breast height (dbh) in 2009 and assessed for general tree health. Study trees had a mean $73.66 \mathrm{~cm} \mathrm{DBH}$. All trial trees were pruned in a manner consistent with American National Standards Institute (ANSI) A300 and ISA best management practices, and according to Entergy Louisiana, LLC. urban tree care specifications of $3.048 \mathrm{~m}$ of clearance from all energized lines and other equipment (Entergy 2014).

Trees were assigned one of eight treatment timings using a randomized complete block design, with six replications to account for differences in site conditions. Timings were as follows: PBZ applied at the time of pruning, 180 days pre-prune, 90 days pre-prune, 30 days pre-prune, 180 days post-prune, 90 days postprune, 30 days post-prune, or untreated control (Table 1). Applications of 22.3\% PBZ (Cambistat 2SC, Rainbow Treecare Scientific Advancements, Minnetonka, Minnesota, U.S.) were initiated in July of 2009 with the 180 days preprune treatment and concluded in July of 2010 with the 180 days post-prune treatment (Table 1). Treatments were timed to coincide with regularly scheduled pruning that occurred in late January/early February of 2010 (Table 1).

PBZ was applied at a rate of 1.81 grams of active ingredient per centimeter diameter at breast height (label rate of PBZ) to the study trees. PBZ was mixed with 11:1 (water: PBZ) ratio to create a ready-to-use solution. All applications were made using a subsurface soil injection system (HTI 2000 Rainbow Treecare Scientific Advancements, Minnetonka, Minnesota, U.S.). Soil injections were applied below the soil surface at a depth of 10 to $15 \mathrm{~cm}$ and $98.4 \mathrm{ml}$ of ready to use solution was applied for every centimeter of trunk diameter. Soil injection sites were spaced evenly at the base of the tree within 30.5 centimeters of the root flare, and applications were made by an ISA Certified Arborist ${ }^{\circledast}$ from Edko, LLC, Shreveport, Louisiana, U.S. (formerly Advanced Applicators Inc.). The mixed solution was injected into the soil surface at 1.034 megapascals.

In late January and early February of 2013, after three growing seasons, all study trees were re-pruned and evaluated by branch length from energized wires, branch re-growth after pruning, and pruning and chipping time. To measure branch re-growth, all trees were pruned to a $3.048 \mathrm{~m}$ clearing standard using an aerial bucket

Table 1. PBZ treatment and application dates for live oak trees (Quercus virginiana) in Baton Rouge, Louisiana, U.S.

\begin{tabular}{llll}
\hline Treatment & $\begin{array}{l}\text { Plant growth } \\
\text { regulator application }\end{array}$ & $\begin{array}{l}\text { \# of trees in } \\
\text { treatment }\end{array}$ & $\begin{array}{l}\text { Application } \\
\text { date }\end{array}$ \\
\hline Untreated control & N/A & $6^{z}$ & N/A \\
180 days pre-prune & PBZ 22.3\% & 6 & 07 July 2009 \\
90 days pre-prune & PBZ 22.3\% & 6 & 15 October 2009 \\
30 days pre-prune & PBZ 22.3\% & 6 & 07 December 2009 \\
At time of pruning & PBZ 22.3\% & 6 & 15 January 2010 \\
30 days post-prune & PBZ 22.3\% & 6 & 16 February 2010 \\
90 days post-prune & PBZ 22.3\% & 6 & 28 April 2010 \\
180 days post-prune & PBZ 22.3\% & 6 & 14 July 2010 \\
\hline
\end{tabular}

${ }^{\mathrm{z}}$ One untreated control tree was removed from data-set due to extreme environmental conditions. 
by a utility subcontractor of Entergy Louisiana, LLC. (Entergy 2014). Measurements were taken of branch re-growth response following initial pruning three years prior. Pruning wounds had been marked with orange marking paint at the time of the pruning and were re-painted in 2011 and 2012. Twenty branches from each study tree were measured from the base of original pruning wound on each cut limb to the longest terminal node. Pruned branches were measured for branch re-growth response and photo documented (Figure 1). Biomass volume measurements were taken using a tape measure to acquire length, width, and height on rectangular stacked pruning excess branch tissue to estimate the total biomass volume.

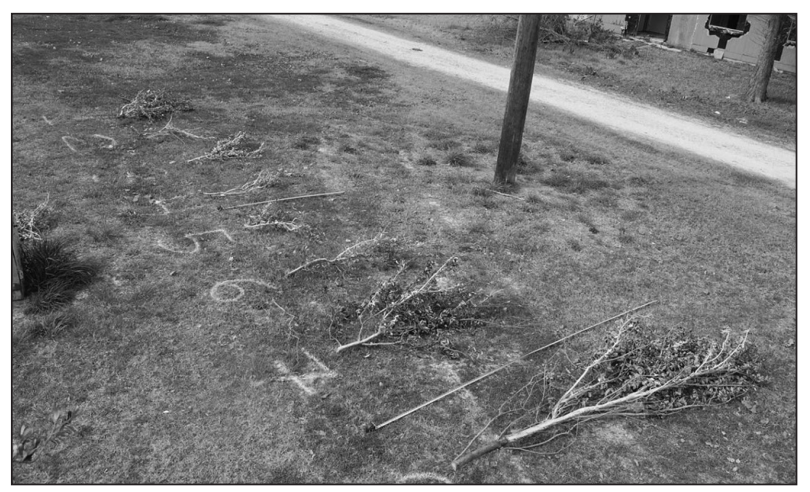

Figure 1. Photograph of branches removed from study trees at time of re-pruning. Branches from a representative live oak study tree with PBZ application at time of pruning, PBZ application 180 days pre-prune, $P B Z$ application 90 days preprune, PBZ application 30 days pre-prune, PBZ application 180 days post-prune, PBZ application 90 days post-prune, PBZ application 30 days post-prune, and control, from left to right, respectively.

The time required to prune each study tree was recorded with a stop watch by an observer. Pruning time recorded included only the time the aerial bucket was in operation from aerial bucket lift to aerial bucket return. Chipping time was measured from the time the pruning crew picked up the first branch of the pile to the last branch processed through the wood chipper (Dayinian 1993). Wood chippers were maintained within $6.10 \mathrm{~m}$ of a given pile of brush and were maintained at $6.10 \mathrm{~m}$ to standardize the chipping times.

All treatments were analyzed with an Analysis of Variance (ANOVA) test. Separations of means for all variables were determined using a Fisher's Least
Significant Difference (LSD) test at a $P<0.05$. Due to high level of variability in growth, the LSD test was used as opposed to a more conservative method.

A cost-benefit analysis was conducted to determine economic differences between live oak trees treated with PBZ at different time points and control trees due to average pruning, chipping, and PBZ application times per tree. The analysis used the standard $\$ 95$ per hour utility vegetation management rate (Goodfellow and Michael 2012). Additionally, it built in $20 \%$ cost sensitivity to account for differences in utility vegetation management rates.

\section{RESULTS}

At the conclusion of the trial, there was significantly shorter branch length, pruned biomass, and shorter pruning and chipping times for trees treated with PBZ $(P<0.05)$.

Across all treatments of PBZ application timings, there was a significant reduction in branch growth (Table 2). Trees treated with PBZ showed reductions in growth, compared to the untreated controls, ranging from $29.7 \%$ for 90 days pre-prune, to $43.2 \%$ for 90 days postprune. Significant differences between the timing of application of PBZ on live oak trees in relation to the pruning event were found (Table 2).

The untreated trees had a mean branch re-growth of $285.8 \mathrm{~cm}$ over three years. One individual had a mean growth of $99.7 \mathrm{~cm}$ over three years. This study tree was found to be an outlier due to extreme environmental conditions and is excluded from the analysis. Treated trees had a mean branch regrowth of $187.6 \mathrm{~cm}$ over three years (Table 2).

Table 2. Mean length of branch re-growth $(\mathrm{cm})$ and percent reduction in branch regrowth for the eight PBZ soil treatment times and control live oak trees (Quercus virginiana).

\begin{tabular}{llll}
\hline Treatment & $\begin{array}{l}\text { Re-growth } \\
(\mathrm{cm})\end{array}$ & $\begin{array}{l}\text { \% reduction in } \\
\text { branch growth }\end{array}$ & $\begin{array}{l}\text { Significance } \\
(P<0.05)\end{array}$ \\
\hline Untreated control & 285.8 & N/A & $\mathrm{A}$ \\
180 days pre-prune & 178.3 & 37.6 & $\mathrm{CD}$ \\
30 days pre-prune & 174.5 & 38.9 & $\mathrm{CDE}$ \\
90 days pre-prune & 199.9 & 30.0 & $\mathrm{~B}$ \\
& & & $\mathrm{DE}$ \\
At time of pruning & 170.2 & 40.4 & \\
& & & $\mathrm{~B}$ \\
30 days post-prune & 197.1 & 31.0 & $\mathrm{E}$ \\
90 days post-prune & 162.1 & 43.2 & $\mathrm{BC}$ \\
180 days post-prune & 186.9 & 34.5 &
\end{tabular}


Table 3. Mean pruning time (minutes) for live oak trees (Quercus virginiana) after PBZ application at different time points.

\begin{tabular}{lll}
\hline Treatment & $\begin{array}{l}\text { Pruning time } \\
\text { (minutes) }\end{array}$ & $\begin{array}{l}\text { Significance } \\
(P<0.05)\end{array}$ \\
\hline Untreated control & 61 & $\mathrm{~A}$ \\
& 23 & $\mathrm{D}$ \\
180 days pre-prune & 30 & $\mathrm{C}$ \\
90 days pre-prune & 25 & $\mathrm{D}$ \\
30 days pre-prune & & $\mathrm{D}$ \\
At time of pruning & 23 & $\mathrm{~B}$ \\
30 days post-prune & 44 & $\mathrm{C}$ \\
90 days post-prune & 31 & $\mathrm{~B}$ \\
180 days post-prune & 45 & \\
\hline $\begin{array}{l}\text { Note: Separation of means was conducted with LSD test of } P<0.05 \text { for dif- } \\
\text { ferences among treatments. }\end{array}$ &
\end{tabular}

Live oak trees treated with PBZ were found to reduce pruning time by $26.2 \%$ for 180 days postprune, to $62.2 \%$ for 180 days pre-prune (Table 3 ). Trees treated with PBZ were found to require significantly shorter pruning times $(P<0.05)$ than untreated trees by $18 \%$ for 90 days post-prune, to $46.6 \%$ for trees treated at time of pruning. Statistical differences were seen among the different treatments (Table 4).

There was a significant reduction in biomass of all PBZ-treated trees compared to the control $(P<0.05)$. The greatest reduction in biomass was seen at the 90 days post-prune application time with an $84 \%$ reduction in biomass (Table 5). Reduction of biomass for all other times ranged from $56 \%$ to $68 \%$ reduction (Table 5).

A range of $39 \%$ to $69 \%$ reduction of labor from pruning and chipping resulted from reduction of biomass due to PBZ applications to live oak trees. When accounting for the nine-minute $\mathrm{PBZ}$ application time per tree, there is a range of $25 \%$ to $56 \%$ reduction in labor due to pruning, chipping, and PBZ application (Table 6). Given
Table 4. Mean chipping time (minutes) of biomass regrowth post application of PBZ at different time points.

\begin{tabular}{lll}
\hline Treatment & $\begin{array}{l}\text { Chipping time } \\
\text { (minutes) }\end{array}$ & $\begin{array}{l}\text { Significance } \\
(P<0.05)\end{array}$ \\
\hline Untreated control & 9.9 & $\mathrm{~B}$ \\
& & $\mathrm{D}$ \\
180 days pre-prune & 7.0 & $\mathrm{D}$ \\
90 days pre-prune & 7.0 & $\mathrm{D}$ \\
30 days pre-prune & 6.8 & $\mathrm{E}$ \\
At time of pruning & 5.3 & $\mathrm{~A}$ \\
& & $\mathrm{C}$ \\
30 days post-prune & 11.1 & $\mathrm{CD}$ \\
$\begin{array}{l}\text { 90 days post-prune } \\
\text { 180 days post-prune }\end{array}$ & 8.1 & 7.4 \\
$\begin{array}{l}\text { Note: Separation of means was conducted with LSD test of } P<0.05 \text { for dif- } \\
\text { ferences among treatments. }\end{array}$
\end{tabular}

Table 5. Volume (L) of pruned biomass from live oak trees (Quercus virginiana) after PBZ treatments.

\begin{tabular}{lll}
\hline Treatment & Pruned biomass (L) & Significance \\
\hline Untreated control & $23,744.0$ & $\mathrm{~A}$ \\
180 days pre-prune & $10,358.0$ & $\mathrm{~B}$ \\
90 days pre-prune & $7,637.1$ & $\mathrm{D}$ \\
30 days pre-prune & $9,228.5$ & $\mathrm{BC}$ \\
& & \\
At time of pruning & $8,593.7$ & $\mathrm{CD}$ \\
& & \\
30 days post-prune & $9,599.0$ & $\mathrm{BC}$ \\
90 days post-prune & $3,706.7$ & $\mathrm{E}$ \\
180 days post-prune & $8,922.6$ & $\mathrm{BCD}$ \\
\hline
\end{tabular}

the reported $\$ 95$ per hour rate for utility pruning, chipping, and PBZ application labor (Goodfellow and Michael 2012) with 20 percent cost sensitivity, the range of labor costs per single utility live oak tree was estimated to be $\$ 81.19$ to $\$ 121.79$ per tree when the application time of PBZ was 30 days post-prune, and a range of $\$ 47.25$ to $\$ 70.87$ per tree when PBZ was applied at the time of pruning (Table 6). Control trees have an estimated pruning and chipping labor cost ranging from $\$ 89.81$ to $\$ 134.71$ per tree (Table 6).

Table 6. Cost-benefit analysis with $20 \%$ sensitivity of labor associated with biomass reduction per tree at each PBZ application time point. Analysis based on mean pruning, chipping, and PBZ application time. All currency is in USD\$.

\begin{tabular}{|c|c|c|c|c|c|c|c|c|}
\hline Treatment & $\begin{array}{l}\text { Pruning time } \\
\text { (minutes) }\end{array}$ & $\begin{array}{l}\text { Chipping time } \\
\text { (minutes) }\end{array}$ & $\begin{array}{l}\text { PBZ application } \\
\text { time (minutes) }\end{array}$ & $\begin{array}{l}\$ 76 / \text { hour } \\
\text { rate }(\$)\end{array}$ & $\begin{array}{l}\text { \$95/hour } \\
\operatorname{rate}^{z}(\$)\end{array}$ & $\begin{array}{l}\$ 114 / \text { hour } \\
\text { rate }(\$)\end{array}$ & $\begin{array}{l}\text { Avg. net } \\
\text { savings }^{\mathrm{y}}(\$)\end{array}$ & $\begin{array}{l}\% \\
\text { savings }\end{array}$ \\
\hline Untreated control & 61 & 9.9 & 0 & 89.81 & 112.26 & 134.71 & - & $0 \%$ \\
\hline 180 days pre-prune & 23 & 7.0 & 9 & 49.40 & 61.75 & 74.10 & 50.51 & $35 \%$ \\
\hline 90 days pre-prune & 30 & 7.0 & 9 & 58.27 & 72.83 & 70.30 & 69.64 & $49 \%$ \\
\hline 30 days pre-prune & 25 & 6.8 & 9 & 51.68 & 64.60 & 60.42 & 77.87 & $55 \%$ \\
\hline At time of pruning & 23 & 5.3 & 9 & 47.25 & 59.06 & 53.77 & 83.41 & $59 \%$ \\
\hline 30 days post-prune & 44 & 11.1 & 9 & 81.19 & 101.49 & 104.69 & 40.98 & $29 \%$ \\
\hline 90 days post-prune & 31 & 8.1 & 9 & 60.93 & 76.16 & 74.29 & 66.31 & $47 \%$ \\
\hline 180 days post-prune & 45 & 7.4 & 9 & 77.77 & 97.22 & 99.56 & 45.25 & $32 \%$ \\
\hline
\end{tabular}

z $\$ 5$ /hour is a current rate for a pruning and chipping utility crew (Goodfellow and Michael 2012).

${ }^{y}$ Average net savings was calculated by subtracting $\$ 95 /$ hour rate of each treatment from the $\$ 95 /$ hour control rate. 


\section{DISCUSSION}

At the conclusion of the trial, all treatments with PBZ showed significantly shorter re-growth, pruning, and chipping times regardless of application time. Trees treated with PBZ showed decreased branch growth of $30.0 \%$ to $43.2 \%$ (Table 2). Although there were significant differences due to treatment times across all variables, high efficacy was seen in all PBZ treatments on live oak trees compared to control. This allows utilities and applicators flexibility when applying PBZ to trees for utility purposes, from 180 days pre-prune to 180 days post-prune on live oak trees. Overall, there was a trend that the greatest differences between treated and control trees were seen at application times ranging from 90 days pre-prune to 90 days post-prune. These results contrast slightly with the current recommendations prescribed in the ISA Utility Specialist Certification Study Guide, which states treatments should be targeted from the time of pruning to two to three months prior to pruning (International Society of Arboriculture 2002).

Reducing the branch length re-growth has a positive impact on pruning crews' ability to rapidly remove brush from the canopy and process biomass. This leads to less potential for dangerous interaction with energized conductors. From a 2001-2006 survey of tree care workers, $21.4 \%$ of fatalities were caused from contact with energized wires (Ball and Vosburg 2010). Although the data does not provide details regarding each fatality's circumstances, it does indicate that a decrease in time workers are in an aerial bucket or using a wood chipper will decrease the potential for injury or a fatal accident (Ball and Blair 2009). Shorter branches allow pruners to better manipulate their removal from the canopy and reduce potential contact with energized conductors. The net reduction in biomass in trees treated with PBZ was significant (Table 5). The reduction in biomass will reduce the frequency of line-clearance crews to dump chips, reduce driving time, and minimize overall time required for line-clearance pruning operations.

The labor cost of pruning and chipping biomass and application of PBZ from an untreated live oak tree with $20 \%$ cost sensitivity ranged from $\$ 89.81$ to $\$ 134.71$ per tree (Table 6). PBZ treatments were found to reduce these labor costs with an estimated net savings per live oak tree of $\$ 33.22$ to $\$ 75.65$ per tree (Table 6). This reduction in cost is exclusively due to pruning, chipping, and PBZ applicator labor and does not account for travel to and from the site. Pruning and chipping labor accounts for an estimated $21 \%$ of costs for utility vegetation management (Mann et al. 1995).

Mean re-growth of branches in response to pruning was significantly different between treated and control trees. Timing between applications was found to be statistically significant, with a strong trend indicating applicators should target PBZ applications on or close to the time of pruning (Table 2). However, applications of PBZ on live oak trees are effective from 180 days pre-prune to 180 days post-prune, resulting in an estimated reduction in pruning costs due to biomass reduction of $42 \%$ to $45 \%$, respectively (Table 6 ). All trees that were treated with PBZ had a significantly shorter appearance than untreated trees. This reduction in branch re-growth reduces the likelihood of branch contact with energized wires. It was observed but not quantified that they were greener in appearance.

Unusually low precipitation in the region led to an atypically low re-growth rate for live oak compared to historical norms. Mean annual precipitation for the Baton Rouge area is $160.22 \mathrm{~cm}$. However, the annual precipitations for the 2009 through 2012 were $147.85 \mathrm{~cm}, 105.39 \mathrm{~cm}, 120.96 \mathrm{~cm}$, and 168.94 $\mathrm{cm}$ for the respective years. This may have caused the difference in efficacy of $\mathrm{PBZ}$ on regrowth rate to previous trials rate of $50 \%-70 \%$ to this study's observed rate of $43 \%$ reduction (Martinez-Trinidad et al. 2011). Limited soil moisture may impact the uptake and translocation of systemic soil applied PBZ.

The amount of time required for crews to prune an individual tree is strongly correlated to branch length due to factors such as a reduction in arborist fatigue, branch handling time, and an easier extraction of limbs from the canopy while working around energized lines. This is not the case for pruning and chipping time at the 30 days postprune PBZ application time (Table 6). This exception is due to factors such as confined work zones that made efficient and safe aerial bucket usage.

Additionally, larger branches lead to a more timeconsuming process of navigating the tree with an aerial bucket. The amount of time between individual cuts is also extended due to the need of repositioning the aerial bucket to reach individual branches. 
Longer branches are more challenging to extricate from the canopy (Mann et al. 1995). After initial cuts are made, there is an increased risk of workmanship error, with longer branches potentially resulting in power interruptions as well as a greater challenge for managing larger branches than smaller branches on the ground for efficient branch processing (Ball and Vosburg 2010). Working with untreated branches averaging $285.8 \mathrm{~cm}$ in length versus $162.1 \mathrm{~cm}$ is dramatically different for the arborist using an aerial bucket (Table 6). This reduction leads to both a reduction in cost of labor for pruning and processing time, as well as a reduction in potential injuries while on a job site (Table 6) (Ball and Vosburg 2010).

Ideally, the timing of PBZ application to live oak trees is between 90 days pre-prune and 90 days postprune (Table1; Table 2; Table 3; Table 4; Table 5; Table 6). Although statistically significant differences exist between the results from application times of PBZ, the maximum of $12.8 \%$ difference in reduction of branch growth may be negligible for the end user, indicating greater flexibility in application timing (Table 2). Additionally, due to the inherent subjectivity in the pruning of the trial trees there is a high level of variability in the branch re-growth data.

Paclobutrazol is a tool that can predictably reduce the vegetative re-growth on Q. virginiana trees pruned for utility line clearance. The application of this tool results in reduced vegetative growth leading to reduced pruning and chipping time by lineclearance crews. This reduction in time decreases the maintenance cost necessary for pruning and increases the safety of pruning crews. The timing of PBZ application on live oak trees in relation to the pruning event, though statistically significant, would not drastically affect operation efficiency on live oak trees in Louisiana. However, the savings in labor for the pruning and processing of the biomass is significant when PBZ is utilized compared to no application of PBZ. Further research is required to understand how the severity of the initial pruning event relates to the quantity and length of resurgent growth.
Acknowledgments. The authors wish to thank Brandon Hughson and Erik Gabbey from Rainbow Treecare Scientific Advancements, Jim Neeser from the Davey Resource Group, and John Dean from Entergy Louisiana, LLC. for their assistance and coordination of

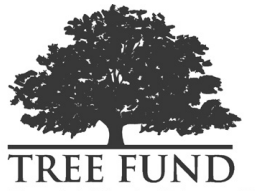
field work. This research was funded, in part, by The TREE Fund, and the authors sincerely thank The TREE Fund for their generous support of this research project.

\section{LITERATURE CITED}

Bai, S., W. Chaney, and Y. Qi. 2004. Response of cambial and shoot growth in trees treated with paclobutrazol. Journal of Arboriculture 30(3):137-145.

Ball, J., and D.F. Blair. 2009. Chipper accidents are more common than reported. Tree Care Industry pp. 8-13.

Ball, J., and S. Vosburg. 2010. A survey of United States tree care companies: Part I: Safety training and fatal accidents. Arboriculture \& Urban Forestry 36(5):224-229.

Burch, P.L., and R.H. Wells. 1995. Tree Growth Evaluated 10 Years After Application of Paclobutrazol Tree Growth Regulator. Down to Earth.

Campbell, R.J. 2012. Weather-Related Power Outages and Electric System Resiliency. Washington, D.C.: Congressional Research Service.

Dayinian, M. 1993. Wood Chip Management. Arborist News 2(2):9-13.

Entergy. 2014. Distribution Vegetation Management Line Clearance Specifications. Louisiana: Entergy.

Gillespie, A., and W. Chaney. 1989. Process modeling of nitrogen effects on carbon assimilation and allocation-A review. Tree Physiology 5(1):99-112.

Goodfellow, J.W., and T.W. Michael. 2012. Public Regulatory Authority Review of the Public Service Companies' Response to 2011 Storms. Connecticut: Townsley Consulting Group, LLC.

ISA. 2002. Utility Specialist Certification Study Guide. International Society of Arboriculture, Champaign, Illinois, U.S. 84 pp.

Jacobs, K., and L. Berg. 2000. Inhibition of fungal pathogens of woody plants by the plant growth regulators paclobutrazol. Pest Management Science 56(5):407-412.

Mann, M., H.A. Holt, W.R. Chaney, W.L. Mills, and R.L. McKenzie. 1995. Tree growth regulators reduce line-clearance trimming time. Journal of Arboriculture 21(4):209-212.

Martinez-Trinidad, T., W.T. Watson, and R.K. Book. 2011. Impact of paclobutrazol on root-pruned live oak. HortTechnology 21(1):46-50. 


\author{
Chris Haugen \\ Rainbow Treecare Scientific Advancements \\ Research and Development \\ Minnetonka, Minnesota 55343, U.S.
}

\author{
Kevin Tucker \\ Jimmy Sanders Inc. \\ Specialty Products \\ Baton Rouge, Louisiana, U.S.
}

Alex Smalling

Edko LLC

Vegetation Management

Shreveport, Louisiana 71107, U.S.

Emily Bick

Rainbow Treecare Scientific Advancements

Research and Development

$11571 \mathrm{~K}$-Tel Drive

Minnetonka, Minnesota 55343, U.S.

\author{
Steve Hoover \\ Entergy \\ Vegetation Management \\ Garyville, Louisiana 70051, U.S.
}

Grant Ehlen

American Electric Power

Vegetation Management

Columbus, Ohio, U.S.

Todd Watson

Texas A\&M University

Ecosystem Science and Management

College Station, Texas 77843, U.S.

Shawn Bernick (corresponding author)

Rainbow Treecare Scientific Advancements

Research and Development

Minnetonka, Minnesota 55343, U.S.

SBernick@treecarescience.com
Résumé. Les effets du régulateur de croissance paclobutrazol sur les chênes de Virginie (Quercus virginiana) ont été évalués afin de déterminer la période optimale d'application et la durée des travaux d'élagage en Louisiane. Les facteurs à considérer comprenaient la longueur de la repousse, la distance séparant la branche du réseau, la durée des travaux délagage et le temps requis pour le déchiquetage des branches coupées. Les données furent évaluées afin de déterminer la période optimale d'application du paclobutrazol en relation avec la période où prenait place les travaux délagage. Les chênes traités avec le paclobutrazol montraient une repousse moindre, une durée des travaux d'élagage et de déchiquetage plus courte comparativement aux arbres témoins quel que soit le moment de l'application. Lapplication de paclobutrazol sur les chênes de Virginie était idéale si effectuée dans les 90 jours avant et les 90 jours suivant lélagage. Économiquement, des gains importants ont été réalisés en utilisant ce produit selon une période s'étendant de 180 jours avant à 180 jours suivant l'élagage, ce qui permet une flexibilité dans l'application de ce produit afin de réduire la croissance des arbres à proximité des réseaux électriques. Les chênes de Virginie traités avec le paclobutrazol ont démontré une croissance réactive significativement moins grande.

Zusammenfassung. In Louisiana wurde der Effekt der Pflanzenwachstumsregulators Paclobutrazol auf Lebenseichen (Quercus virginiana) bewertet, um das optimale Zeitfenster der Applikation und des Rückschnitts zu bestimmen. Die dabei berücksichtigten Variablen schlossen Länge des Neuaustriebs der Äste, Distanz des Astes zum Leittrieb, Schnittzeitdauer und Hächselzeit ein. Die Daten wurden bewertet, um die optimale Zeit für die Applikation von Paclobutrazol in relativer Zeit zum Rückschnitt zu bestimmen. Mit Paclobutrazol behandelte Lebenseichen hatten signifikant reduzierten Astneuzuwachs, Schnitt- und Hächselzeit im Vergleich zu der Kontrollgruppe, unabhängig von der Applikationszeit. Die Applikation von Paclobutrazol auf Lebenseichen ist ideal innerhalb von 90 Tagen vor und 90 Tagen nach dem Rückschnitt. Unter ökonomischen Aspekten wurden signifikante Vorteile in einem Zeitraum von 180 Tagen vor bis 180 Tagen nach dem Schnitt entdeckt, was eine Flexibilität der Applikationszeit zum Rückschnitt im Bereich von Oberlandleitungen zulässt. Mit Paclobutrazol behandelte Lebenseichen demonstrieren deutlich weniger Nachwuchs.

Resumen. Se evaluó el efecto del regulador del crecimiento paclobutrazol en encinos (Quercus virginiana) para determinar el momento óptimo de aplicación y la época de poda en Luisiana. Las variables consideradas son la longitud del rebrote, la distancia al conductor, la época de poda y la biomasa obtenida. Los datos se evaluaron para determinar el momento de aplicación ideal de paclobutrazol en relación con el tiempo de la poda. Los árboles de encino tratados con paclobutrazol redujeron significativamente el rebrote, el tiempo de poda y la biomasa, en comparación con el los árboles de control, independientemente de la época de aplicación. La aplicación de paclobutrazol fue idealizado en los 90 días previos y los 90 días después de la poda. Económicamente, se encontraron aumentos significativos por la utilización de esta herramienta que van desde los 180 días previos a los 180 días posteriores de la poda, lo que permite la flexibilidad de la sincronización para reducir el crecimiento de los árboles cerca de líneas eléctricas. Los árboles de encino tratados con Paclobutrazol mostraron significativamente menos re-crecimiento. 